\title{
Corrigendum
}

\section{Effects of Two Types of Calorie Restriction on Methylation Levels of Adiponectin Receptor 1 (AdipoR1) and Leptin Receptor Overlapping Transcript (Leprot) in a MMTV-TGF- $\alpha$ Breast Cancer Mouse Model - CORRIGENDUM}

M.B. Cicekdal, B.T. Kazan, B.G. Tuna, U. Ozorhan, I.D. Ekici, F. Zhu, O. Suakar, A. Kuskucu, O.F. Bayrak, K. Arcaro, M.P. Cleary and S. Dogan

(First published online $5^{\text {th }}$ November 2019)

doi: https://doi.org/10.1017/S0007114519002757

Original text and correction

\section{Original text}

M.B. Cicekdal, B.T. Kazan, B.G. Tuna, U. Ozorhan, I.D. Ekici, F. Zhu, O. Suakar, A. Kuskucu, O.F. Bayrak, K. Arcaro, M.P. Cleary, S. Dogan.

\section{Correction}

The name of the authors are listed below. The name of the two of the authors (O. ATASAYAN ${ }^{8}$, B. YILMAZ) were missed in previous version. Therefore, please replace the list of the authors in the manuscript with the correct list of the authors listed below.

Munevver B. CICEKDAL ${ }^{1}$, B.T. KAZAN ${ }^{1}$, B.G. TUNA ${ }^{2}$, U. OZORHAN ${ }^{1}$, I.D. Ekici ${ }^{3}$, F. ZHU ${ }^{4}$, O. Suakar ${ }^{5}$, A. KUSKUCU ${ }^{5}$, O.F. BAYRAK ${ }^{5}$,

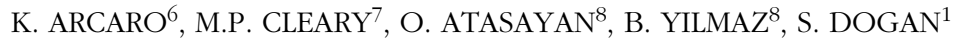

Departments of Medical Biology ${ }^{1}$, Biophysics ${ }^{2}$, Pathology ${ }^{3}$, Medical Genetics $^{5}$, Physiology ${ }^{8}$, Yeditepe University, School of Medicine, Istanbul, TURKEY

Department of Biochemistry and Molecular Biology, School of Basic Medicine, Huazhong University of Science and Technology, CHINA $^{4}$

Department of Veterinary and Animal Sciences, College of Natural Sciences, University of Massachusetts, Amherst, MA, USA ${ }^{6}$

Hormel Institute Medical Research Center, University of Minnesota, Austin, MN $55912^{7}$ 